\title{
Ghrelin- and preproghrelin-immunoreactive cells in atrophic body gastritis
}

Primeira submissão em 10/02/11 Última submissão em 10/02/11 Aceito para publicação em 15/03/11 Publicado em 20/10/11

\author{
Células imunorreativas a grelina e preprogrelina na gastrite atrófica do corpo
}

Letícia F. Moreira'; Alfredo J. A. Barbosa²

\begin{abstract}
key words abstract
Gastritis

Introduction: Chrelin is a 28 amino acid peptide mainly secreted by endocrine cells of the gastric

Atrophic body gastritis

mucosa, which is believed to have a modulating effect on cell growth. Objective: To assess the presence of ghrelin and its precursor preproghrelin molecule in endocrine hyperplasias associated with Ghrelin atrophic body gastritis (ABG). Material and methods: Endoscopic biopsies from 54 patients with $A B G$ Preproghrelin

Endocrine cells were processed for immunohistochemistry and specific antibodies against ghrelin, preproghrelin and chromogranin were applied. We assessed the immunoreactive cells in endocrine hyperplasia from the atrophic mucosa and intestinal and pseudo-antral metaplasia areas. Results: There was ghrelin expression Endocrine hyperplasia in a variable number of hyperplastic endocrine cells from all patients studied. There was a statistically significant difference in the number of hyperplastic nodules with more than $50 \%$ immunostained cells for chromogranin and ghrelin and for chromogranin and preproghrelin. The mean number of hyperplastic nodules identified by chromogranin was 8.6 per patient. Most nodules were immunoreactive to ghrelin and preproghrelin. The presence of ghrelin and preproghrelin expression was uncommon in glands showing intestinal metaplasia: four $(9.5 \%)$ and nine $(21.4 \%)$ cases, respectively. In contrast, they were relatively frequent in pseudo-antral metaplasia areas: $37(72.5 \%)$ and $26(50.9 \%)$ cases, respectively. Conclusion: Ghrelin- and preproghrelin-immunoreactive cells are frequently present in endocrine hyperplasias associated with ABG. However, further studies are required to determine to what extent these hormones act as modulators of hyperplastic nodular growth and evolution.
\end{abstract}

\section{resumo}

Introdução: Grelina é um peptídeo de 28 aminoácidos secretado principalmente pelas células endócrinas da mucosa gástrica, acreditando-se que apresente ação moduladora relacionada com o crescimento celular. Objetivo: Estudar a presença de grelina e da molécula precursora preprogrelina na hiperplasia endócrina associada à gastrite atrófica do corpo (GAC). Material e métodos: Biópsias endoscópicas de 54 pacientes com GAC foram processadas para imuno-histoquímica, e anticorpos específicos contra grelina, preprogrelina e cromogranina foram utilizados. As células imunorreativas foram examinadas na hiperplasia endócrina presente na mucosa atrófica e nas áreas de metaplasia intestinal e pseudoantral. Resultados: Ocorreu expressão de grelina em número variável de células endócrinas hiperplásicas em todos os pacientes estudados. Diferença estatisticamente significativa foi encontrada entre a frequência de nódulos hiperplásicos com mais de 50\% de células imunomarcadas por cromogranina e grelina ou por cromogranina e preprogrelina. O número médio de nódulos hiperplásicos por paciente demonstrado pela cromogranina foi de 8,6. A maioria desses nódulos apresentou células imunorreativas para grelina e preprogrelina, respectivamente, 5,1 e 5,6, em média. A presença da expressão imuno-histoquímica de grelina e preprogrelina foi incomum em glândulas exibindo metaplasia intestinal, respectivamente, em quatro $(9,5 \%)$ e nove $(21,4 \%)$ casos e foram frequentes nas áreas de metaplasia pseudoantral em, respectivamente, 37 (72,5\%) e 26 (50,9\%) casos. Conclusão: Células imunorreativas a grelina e preprogrelina estão presentes na hiperplasia endócrina associada à GAC. Entretanto, mais estudos são necessários para saber até que ponto esses hormônios estão atuando como moduladores do crescimento e a evolução desses nódulos hiperplásicos.

\section{unitermos}

Gastrite

Gastrite atrófica do corpo

Grelina

Preprogrelina

Células endócrinas

Hiperplasia endócrina

1. Mestra em Patologia Ceral; doutoranda em Patologia pela Universidade Federal de Minas Cerais (UFMG).

2. Doutor em Ciências; professor titular da Faculdade de Medicina da UFMG. 


\section{Introduction}

Ghrelin is a 28-amino-acid peptide first described in 1999 with a strong growth hormone-releasing action mediated by the activation of the growth hormone secretagogue receptor ${ }^{(8,9)}$. This peptide is known to be secreted mainly by endocrine cells present in the oxyntic mucosa of the stomach, which account for about $80 \%$ of the plasma levels of this hormone ${ }^{(5)}$. A growing number of studies have indicated that ghrelin-immunoreactive cells are present in smaller numbers in other organs ${ }^{(5,10)}$. In addition to stimulating growth hormone secretion, ghrelin also stimulates appetite and a positive energy balance ${ }^{(22)}$. It also acts on the hypothalamus and on the exocrine and endocrine pancreas, among other reported activities ${ }^{(2,6,12)}$. Ghrelin is derived from post-translational cleavage of the precursor molecule preproghrelin. Endocrine cells that express ghrelin have been described in neuroendocrine tumors from different tissues ${ }^{(13,15,19)}$. Type I gastric neuroendocrine tumors (carcinoid tumors) are believed to originate from nodules of hyperplasic endocrine cells usually present in the atrophic gastric mucosa of patients with autoimmune gastritis(18). We have recently shown that ghrelin- and preproghrelinimmunoreactive cells are variably present in type I gastric carcinoids and in the adjacent endocrine hyperplastic nodules of patients with atrophic body gastritis ${ }^{(14)}$. Given the multiple functions proposed for ghrelin, including a possible role in controlling cell proliferation, we decided to determine the presence of this peptide and its precursor molecule preproghrelin in different types of endocrine cell hyperplasia associated with atrophic body gastritis. We also decide to study the presence of these immunoreactive cells in areas of intestinal and pseudopyloric metaplasia which are frequent changes observed in the atrophic mucosa of patients with advanced stages of atrophic body gastritis (ABG).

\section{Material and methods}

Paraffin blocks of endoscopic biopsies from 54 patients with histologically well recognized $A B G$ were obtained from the Alfa Institute of Gastroenterology, Federal University of Minas Gerais (UFMG), Belo Horizonte, Minas Gerais, Brazil. Hematoxylin and eosin (HE) slides of antral and oxyntic mucosa from each case were re-examined and the previous histological diagnoses were confirmed. New $4 \mu \mathrm{m}$ thick paraffin sections were obtained for staining with the combined Alcian blue-periodic acid-Schiff
(PAS/Ab) technique, and for immunohistochemistry. $\mathrm{PAS} / \mathrm{Ab}$ staining was necessary to confirm the presence of intestinal metaplasia and of PAS-positive mucin-producing glands (pseudopyloric metaplasia). Immunohistochemical staining was performed by pretreating histological sections in antigen retrieval solution (citrate buffer retrieval solution, pH 6, Dako Laboratories, USA) in a water bath at $98^{\circ} \mathrm{C}$ for 20 minutes and subsequent cooling at room temperature. The following primary antibodies were used: a) monoclonal antibodies against chromogranin $\mathrm{A}$ (Novocastra Laboratories, UK), working dilution 1:150, to confirm the presence of neuroendocrine cell hyperplasia; b) polyclonal antibodies raised in rabbits against human ghrelin, working dilution 1:1500, and preproghrelin, working dilution 1:4000 (Phoenix Pharmaceuticals, USA). For the purpose of the present study two types of endocrine cell hyperplasia were considered, i.e., (1) nodular endocrine cell hyperplasia, characterized by small clusters of chromogranin-positive cells immersed in the connective tissue of the lamina propria, and (2) immunoreactive cells present in the glandular wall, either as isolated cells or cells acquiring the so-called linear hyperplasia format ${ }^{(20)}$. The presence of immunohistochemical expression of ghrelinand preproghrelin-immunoreactive cells was evaluated in the glands presenting intestinal metaplasia, mucin-secreting glands (so-called pseudopyloric metaplasia), and in the nodular and diffuse endocrine cell hyperplasia.

The study was approved by the Ethics Committee (COEP 479/04) of the UFMG, Brazil.

\section{Results}

Of the 54 patients studied, 42 (77.8\%) were females and $12(22.2 \%)$ were males. The mean age of male patients was $58 \pm 19$ years and the mean age of female patients was 53 \pm 14 years. The histological pattern of the gastric mucosa was similar in almost all the 54 patients studied, showing diffuse involvement of the corpus mucosa by severe chronic atrophic gastritis. Most patients exhibited areas of intestinal and pseudopyloric metaplasia throughout the gastric mucosa of the body, and lymphoid follicles (Figure 1). The gastric mucosa of the antrum was histologically normal or presented minimal changes. Areas of intestinal metaplasia and pseudopyloric metaplasia were present in sections from $42(77.8 \%)$ and 51 (94.4\%) patients, respectively (Table 1). The atrophic body gastric mucosa of all 54 patients exhibited endocrine cell hyperplasia demonstrated 


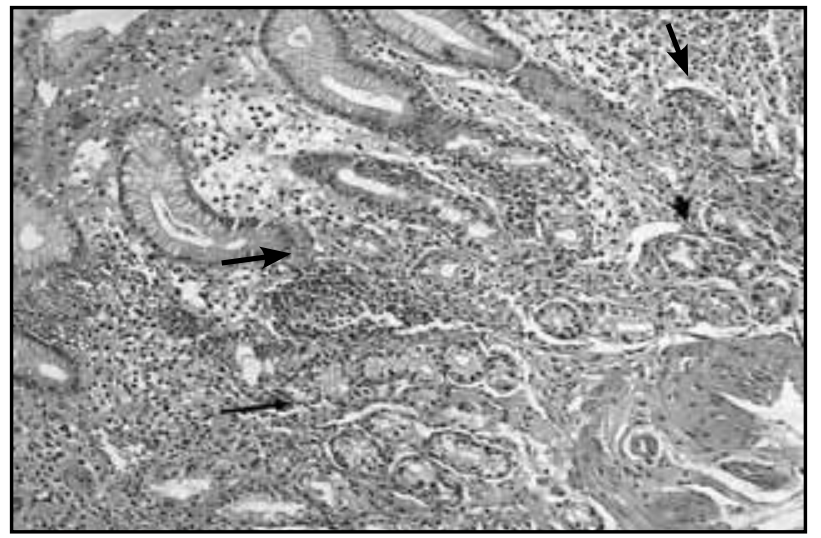

Figure 1 - Oxyntic gastric mucosa of patient with advanced atrophic body showing: diffuse mononuclear cell infiltration of the entire thickness of the lamina propria; few remained acidopeptic glands (short arrow), and pseudopyloric metaplasia (long arrow) (HE staining, 100x)

HE: hematoxylin and eosin.

by chromogranin staining. Fifty-one patients $(94.4 \%)$ had multiple hyperplasic endocrine nodules in the lamina propria in addition to diffuse endocrine hyperplasia, and three (5.6\%) presented diffuse endocrine cell hyperplasia without the presence of hyperplasic nodules. Some of the hyperplasic nodules were reasonably apparent in the HE sections, but most of them were detected after chromogranin staining (Figure 2). The immunohistochemical expression of ghrelin and preproghrelin was variably present in hyperplasic endocrine cells from all patients studied (Figure 3).

Most of the hyperplasic nodules also presented variable number of immunoreactive cells to chromogranin, ghrelin and preproghrelin, but only those nodules with more than $50 \%$ of immunoreactive cells were considered for comparative analysis between the different antibodies

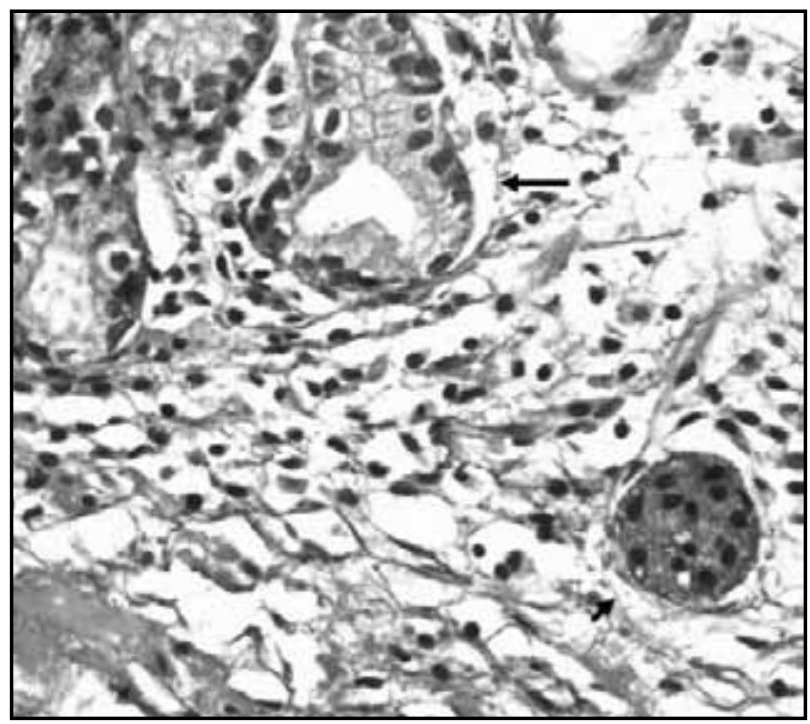

Figure 2 - Immunoreactive cells to chromogranin in diffuse (long arrow) and nodular (short arrow) endocrine cell hyperplasia of patient with $A B G$ (IHQ staining, 400x) $A B G$ : atrophic body gastritis; IHQ: immunohistochemical. used. The mean number of hyperplasic nodules per patient demonstrated by chromogranin staining was 8.6. Most of these hyperplasic nodules presented ghrelin- and preproghrelin-immunoreactive cells, $5.1(p=0.004)$ and $5.6(p=0.018)$, respectively (Tables 2 and $\mathbf{3})$.

Ghrelin- and preproghrelin-immunoreactive cells were scarcely observed in glands exhibiting intestinal metaplasia, with four (9.5\%) and nine (21.4\%) cases presenting these types of epithelial changes, respectively. In contrast, in areas of pseudopyloric metaplasia ghrelin- and preproghrelinimmunoreactive cells were present in many patients with this type of metaplasia, 37 (72.5\%) and 26 (50.9\%), respectively (Table 1) (Figure 3).

\begin{tabular}{|c|c|c|c|}
\hline \multirow{2}{*}{$\begin{array}{l}\text { Ir } \\
\text { g } \\
\text { Table } 1 \text { W } \\
\text { Type of } \\
\text { metaplasia }\end{array}$} & \multicolumn{3}{|c|}{$\begin{array}{l}\text { Immunohistochemical expression of } \\
\text { ghrelin and preproghrelin in glands } \\
\text { with intestinal metaplasia and in glands with } \\
\text { pseudopyloric metaplasia in patients } \\
\text { with ABG }\end{array}$} \\
\hline & a & $\begin{array}{l}\text { Ghrelin } \\
n(\%)\end{array}$ & $\begin{array}{c}\text { Preproghrelin } \\
n(\%)\end{array}$ \\
\hline Intestinal & 42 & $4(9.5 \%)$ & $9(21$. \\
\hline Psudopylor & 51 & 37 (72.5\%) & 26 (50.9\%) \\
\hline
\end{tabular}

ABG: atrophic body gastritis.

Number of endocrine hyperplasic nodules per patient containing more than $50 \%$ of immunoreactive endocrine cells to

Table 2 chromogranin A and ghrelin

\begin{tabular}{l|c|c|c}
\hline $\begin{array}{l}\text { Immunoreaction } \\
\text { to }\end{array}$ & $\begin{array}{c}\text { Mean } \\
\pm S D\end{array}$ & $\begin{array}{c}\text { Paired } \\
t \text { test }\end{array}$ & $p$ \\
\hline Chromogranin & $8.6 \pm$ & & \\
A & 10.1 & & \\
\hline Ghrelin & $5.1 \pm$ & 3.01 & 0.004 \\
\hline
\end{tabular}

SD: standard deviation.

Number of endocrine hyperplasic nodules per patient containing more than $50 \%$ of immunoreactive endocrine cells to

Table 3 chromogranin A and preproghrelin

\begin{tabular}{l|c|c|c}
\hline Immunoreaction & $\begin{array}{c}\text { Mean } \\
\pm S D\end{array}$ & $\begin{array}{c}\text { Paired } \\
t \text { test }\end{array}$ & $p$ \\
\hline to & $\begin{array}{l}\text { SD } \\
\text { Chromogranin }\end{array}$ & $\begin{array}{l} \\
10.1\end{array}$ & \\
\hline A & 10.1 & 2.42 & 0.0189 \\
\hline Preproghrelin & $5.6 \pm$ & & \\
\hline
\end{tabular}

SD: standard deviation. 


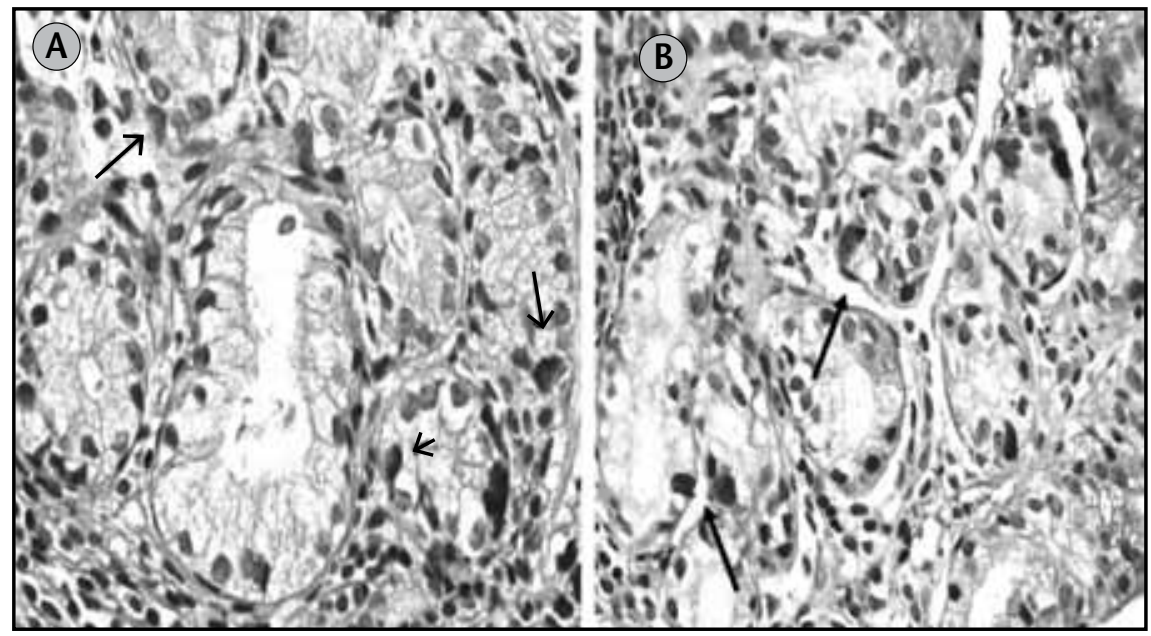

Figure 3 - Diffuse hyperplasic immunoreactive cells (arrows) to ghrelin $(A)$ and to preproghrelin $(B)$ in pseudopyloric metaplasia of gastric mucosa of patient with $A B G$ (IHQ staining, 400x)

ABG: atrophic body gastritis; IHQ: immunohistochemical.

\section{Discussion}

The atrophy of specialized glands of the gastric mucosa associated with chronic inflammation is a common pathological condition in humans. In general, the more severe cases of atrophy of the gastric mucosa do not involve diagnostic difficulties by the two methods commonly used, i.e., endoscopic and histopathological examinations. The current importance of the recognition of gastric mucosal atrophy is the frequency at which this condition is associated with the development of precancerous lesions, i.e., intestinal metaplasia and dysplasia of the gastric epithelium, which may develop into gastric cancer in the sequence known as Correa cascade ${ }^{(4)}$. The two pathological conditions most frequently associated with the development of gastric mucosa atrophy are $\mathrm{H}$. pyloriassociated multifocal chronic gastritis and $A B G$, which in most cases has autoimmune etiology. Being selective for the oxyntic mucosa, autoimmune gastritis leads to progressive loss of parietal cells and chief cells, resulting in the majority of clinical manifestations presented by patients in the later stages of the disease, due to the occurrence of achlorhydria, hypergastrinemia, anemia and their consequences.

It is known that the development of autoimmune gastritis, with or without pernicious anemia, is more common among members of one family in successive generations. Although this is not clearly explained, it is assumed that there is a propensity to develop anti-parietal cell antibodies in genetically predisposed individuals. The existence of genetic predisposition contributing to the induction of atrophy of the oxyntic glands is suspected since $A B G$ is often associated with other diseases with an immunological background. Moreover, racial preferences seem to exist since this disease appears to be significantly more conspicuous in Caucasian than in Asian patients $(1,7,16,21)$. Despite all of this evidence, the mechanisms of inheritance and the importance of environmental factors related to $A B G$ are not known. Among the putative environmental factors, the bacterium H. pylori has been cited as the most important ${ }^{(17)}$. All patients in this study were negative for $H$. pylori infection which is expected to occur in cases of severe atrophy of the gastric mucosa, regardless its etiology. Among the patients studied here, women prevailed over men and age was similar in both groups, $58 \pm 19$ and $53 \pm 14$ years, respectively. These data are similar to most of those reported in the western literature ${ }^{(3,11)}$.

The gastric mucosa of the body is rich in neuroendocrine cells that occur in the crypts between the parietal cells, mucus-secreting cells and chief cells. Interestingly, in patients with $A B G$ these neuroendocrine cells become hyperplasic under the constant stimulus of gastrin, contrary to what occurs with the parietal cells, which virtually cease to exist in the more advanced stages of the disease. The hyperplasia of neuroendocrine cells occurs both in the wall of the crypts (diffuse and linear hyperplasia), and forming hyperplasic nodules in the intimacy of the connective tissue of the lamina propria ${ }^{(20)}$. It is frequently assumed that the latter type of hyperplasia is a first step towards the development of gastric neuroendocrine tumor type I. There are no recognized factors responsible for the progression of hyperplasic nodules to cancer. Thus studies that address morphological, biochemical and evolutionary 
aspects of these hyperplasic lesions may be useful in improving our understanding of the pathogenesis of neuroendocrine tumors of the stomach. In a previous study we observed that both ghrelin peptide and its precursor molecule preproghrelin are present in a large number of neoplasic endocrine cells in gastric neuroendocrine tumors associated with $A B G^{(14)}$. Other studies have shown that ghrelin is present not only in neuroendocrine tumors of the stomach but also in neuroendocrine tumors in other locations ${ }^{(6,13)}$.

It is known that ghrelin-producing cells are present in different tissues, including the intestinal mucosa, however sparingly and inconstantly. In contrast, in the body gastric mucosa these cells reach their highest density and are considered to be the main source of plasma ghrelin ${ }^{(8,9)}$. In the present study ghrelin- and preproghrelin-immunoreactive cells showed similar frequencies both in areas of intestinal metaplasia (9.5\% and $21.4 \%$, respectively) and in areas of pseudopyloric metaplasia ( $72.5 \%$ and $50.9 \%$, respectively). These results show that ghrelin-producing cells was uncommon in areas of intestinal metaplasia and, conversely, was frequent in areas of pseudopyloric metaplasia, the latter showing gastric differentiation. Therefore, regarding the differentiation of endocrine elements, one may assume that the areas of intestinal metaplasia and pseudopyloric metaplasia, present in the gastric mucosa of patients with
$A B G$, and consequently with autoimmune gastritis, should still retain many of the genetic characteristics of the original tissues they represent.

We conclude that the ghrelin- and preproghrelinimmunoreactive cells are frequently found in the different types of endocrine hyperplasia of the gastric mucosa in advanced stages of $A B G$. However, these peptides should not be used as immunohistochemical markers for the endocrine hyperplasia that occurs in $A B G$, since they are significantly less sensitive than chromogranin. Ghrelin- and preproghrelin-immunoreactive cells occur in a relatively frequent manner in glands with pseudopyloric metaplasia and are uncommon in glands with intestinal metaplasia, two types of histological changes frequently seen in ABG. These cells are frequently present in nodular endocrine hyperplasia of patients with $A B G$. However, the extent to which the proliferation of hyperplasic nodules and their progression to cancer are under the influence of these peptides remains a matter for further research.

\section{Acknowledgements}

The authors thank Dr. Eugênio M. A. Goulart for the helpful technical assistance in statistics.

\section{References}

1. ALONSO, M. et al. Plasma ghrelin concentrations in type 1 diabetic patients with autoimmune atrophic gastritis. Eur J Gastroenterol, v. 157, p. 763-9, 2007.

2. BALDELLI, R. et al. Ghrelin: a new hormone with endocrine and non-endocrine activities. Pediatr Endocrinol Rev, v. 2, n. 1, p. 8-14, 2004.

3. CHLUMSKA, A. et al. Autoimmune gastritis. A clinicopathologic study of 25 cases. Cesk Patol, v. 41, p. 137-42, 2005.

4. CORREA, P. Chronic gastritis as a cancer precursor. Scand J Gastroenterol Suppl, v. 104, p. 131-6, 1984.

5. DATE, Y. et al. Ghrelin, a novel growth hormonereleasing acylated peptide, is synthesised in a distinct endocrine cell type in the gastrointestinal tracts of rats and humans. Endocrinology, v. 141, p. 4255-61, 2000.

6. IWAKURA, H. et al. Ghrelin expression in islet cell tumors: augmented expression of ghrelin in a case of glucagonoma with multiple endocrine neoplasm type I. J Clin Endocrinol Metab, v. 87, p. 4885-8, 2002.
7. KEKKI, M. et al. Classification, principles and genetics of chronic gastritis. Scan J Gastroenterol, v. 22, Suppl. 141, p. 1-28, 1987.

8. KOJIMA, M. et al. Ghrelin is a growth-hormone-releasing acylated peptide from stomach. Nature, v. 402, p. 656-60, 1999.

9. KOJIMA, M.; HOSODA, H.; KANGAWA, K. Purification and distribution of ghrelin: the natural endogenous ligand for the GH (growth hormone) secretagogue receptor. Horm Res, v. 56, Suppl., p. 93-7, 2001.

10. KORBONITS, M. et al. The expression of the GHS receptor ligand ghrelin in normal and abnormal human pituitary and other NE tumors. J Clin Endocrinol Metab, v. 86, n. 2, p. 881-7, 2001.

11. LAHNER, E. et al. Occurrence and risk factors for autoimmune thyroid disease in patients with atrophic body gastritis. Am J Med, v. 121, p. 136-41, 2008.

12. LELY, A. J. et al. Biological, phisiological, pathophysiological and pharmacological aspects of ghrelin. Endocr, v. 25, p. 426-57, 2004. 
13. LEONITIOU, C. A. et al. Ghrelin in neuroendocrine organs and tumours. Pituitary, v. 10, n. 3, p. 213-25, 2007.

14. MOREIRA, L. F.; CARVALHO, M. R. N.; BARBOSA, A. J. A. Ghrelin-, and pré-proghrelin immunoreactive cells in gastric neuroendocrine tumors associated with atrophic body gastritis. J Bras Patol Med Lab, v. 46, p. 329-34, 2010.

15. PAPOTTI, M. et al. Grelin-producing endocrine tumors of the stomach and intestine. J Clin Endocrinol Metab, v. 86, n. 10, p. 5052-9, 2001.

16. PARK, J. Y. et al. Gastric lesions in patients with autoimmune metaplastic atrophic gastritis (AMAG) in a tertiary care setting. Am J Surg Pathol, v. 34, p. 1591-8, 2010.

17. PRESOTTO, F. et al. Helicobacter pylori infection and gastric autoimmune diseases: is there a link? Helicobacter, v. 8, p. 578-84, 2003.
18. RINDI, G. et al. Gastric carcinoids and neuroendocrine carcinomas: pathogenesis, pathology and behavior clinicopathologic analysis of 205 cases. World J Surg, v. 20, p. 168-72, 1996.

19. RINDI, G. et al. Ghrelin expression in gut endocrine growths. Histochem Cell Biol, v. 117, n. 6, p. 521-5, 2002.

20. SOLCIA, E. et al. Histopathological classification of nonantralgastric endocrine growths in man. Digestion, v. 41, p. 185-200, 1988.

21. TOZZOLI, R. Recent advances in diagnostic technologies and their impact in autoimmune diseases. Autoimmun Rev, v. 10, p. 80-3, 2007.

22. WANG, H. S. et al. Elevated serun ghrelin exerts an orexigenic effect that may maintain body mass index in patients with metastatic neuroendocrine tumors. J Mol Neurosci, v. 33, p. 225-31, 2007. 